\title{
Correction to: Bioaccumulation of Zinc and Copper in Tissues of Chicken Fed Corn Grain Irrigated with Different Water Regimes
}

\author{
Zill E Huma ${ }^{1} \cdot$ Zafar Iqbal Khan $^{1} \cdot$ ljaz Rasool Noorka $^{2} \cdot$ Kafeel Ahmad $^{1} \cdot$ Ali R. Bayat $^{3} \cdot$ Kinza Wajid $^{1}$
}

Published online: 22 June 2019

(c) University of Tehran 2019

\section{Correction to: \\ International Journal of Environmental Research \\ https://doi.org/10.1007/s41742-019-00211-x}

The article listed above was initially published with incorrect first author name and incomplete acknowledgements.

Upon publication of this Correction, the first author name changed to "Zill E Huma".

This article is a part of thesis work of Author Zill E Huma, a Ph. D. Scholar of Department of Botany.

Author name corrected in original article.

The original article can be found online at https://doi.org/10.1007/ s41742-019-00211-x.

Kinza Wajid

knzwajid@gmail.com

1 Department of Botany, University of Sargodha, Sargodha,

Pakistan

2 Department of Plant Breeding and Genetics, University College of Agriculture, University of Sargodha, Sargodha, Pakistan

3 Milk Production Solutions, Green Technology, Natural Resources Institute Finland (Luke), 31600 Jokioinen, Finland 